\title{
'Unsettling Coyote: Engaging with Indigenous Canadian Theories of Eco-Sexuality in Gail Anderson-Dargatz's The Cure for Death by Lightning (1996)'
}

\section{Alice Higgs ${ }^{1}$}

Gail Anderson-Dargatz's The Cure for Death by Lightning (1996) is a novel whose narrative is haunted by the elusive Indigenous trickster figure, Coyote. After what is believed to be a bear attack on a young girl in the settler community, the novel's protagonist, Beth Weeks, finds herself feeling that she too is being followed by something unknown. Her mother's Shuswap friend and matriarchal figure, Bertha, introduces the concept that the figure haunting the woods is not a bear, but is in fact men who have been possessed by Coyote. A conflict thus emerges between the settler and Shuswap characters and their approach to the non-human animals in the text, as the characters try to contend with what type of danger lurks in the bush, threatening both their livestock and their young women.

Anderson-Dargatz grew up in the Shuswap-Thompson region of British Columbia, an area that she acknowledges is engrained with the history and stories of the Secwepemc, or Shuswap Nation. She states that 'we live with Coyote every day here in the Shuswap' and that they 'have an uncanny ability to appear and disappear out of and into nowhere...You'd swear they were transformers, magic', referring to both the narratives that underpin the real coyotes that frequent the landscape and the elusive trickster figure in numerous stories belonging to a number of North American Indigenous Nations. ${ }^{2}$ In addition, Anderson-Dargatz credits her parents with being talented storytellers, stating that they would combine ghosts and magic realism into

\footnotetext{
${ }^{1}$ I am extremely grateful to the editor of the journal as well as the two anonymous peer reviewers for their comments and suggestions.

${ }^{2}$ Katy Wimherst, "Interview with Gail Anderson-Dargatz," Serendipity, (2009), accessed January 2021, http://www.magicalrealism.co.uk/view.php?story=113.
} 
their narratives on the settler history of the region. The Cure for Death by Lightning then, is heavily influenced and informed by an awareness of the conflict between the settler and Shuswap Nation of the region, including the historical displacement that took place and the continuing arguments regarding territory and authority in British Columbia.

This article will argue that The Cure for Death by Lightning is a novel that attempts to make a meaningful and serious engagement with the Shuswap figure of Coyote. In doing so, it raises vital questions regarding the extent to which a settler writer can and should appropriately engage with an Indigenous story. Moreover, through a focus on both the material animals in the novel, such as domesticated farm animals and the wild coyotes of the bush, and also the representation of Coyote and the Shuswap characters, this article will argue that Anderson-Dargatz encourages a re-evaluation of the way in which we engage with non-human animals, introducing an eco-sexual framework that encourages empathy and kinship with all beings. By using Kim TallBear's (Sisseton Wahpeton Oyate) and Melissa K. Nelson's (Anishinaabe/Métis) definition of eco-sexuality, it will argue that the novel pushes for the centring of Indigenous knowledge in building more sustainable relations with animals. However, it will also acknowledge that despite this eco-sexual engagement, the novel ultimately still continues to centre the settler experience in its narrative, encapsulating and enacting a form of displacement in its very construction.

Issues of territory and governance in terms of environmental policy are an ongoing issue in British Columbia. In April 2020, a bear swam ashore on Hanson Island in British Columbia's Broughton archipelago in search of food. His proximity to humans became a concern to the wildlife management organisation in the area, whose normal practice is to kill bears that get too close or become too comfortable in 
human company. However, local Indigenous groups, namely the Mamalilikulla First Nations, whose territory encompasses this island and by whom the bear was affectionately named Mali, put up resistance to this policy, asserting their right to govern their territories and the human-bear relationships within them. Mike Willie, hereditary chief of the Kwikwasut'inuxw Nation, who oversaw the campaign to protect Mali stated 'We don't want our bears killed any more...We have the right to govern within our own traditional territories and we have inherent rights and we have title.' 3 As such, an article written on the incident in The Guardian maintains that: 'This bear's death was averted through an unlikely partnership between local Indigenous groups and conservation officers, raising hopes of a more holistic approach to wildlife management with greater Indigenous input.'4 Mali was instead captured and relocated to a site on British Columbia's mainland. The success of this outcome, George Heyman, the province's Minister of Environment, says, was motivated by 'desire for reconciliation' with Indigenous peoples, which 'helped guide the process'. However, more than this, the outcome gestures towards a growing autonomy of the First Nations People, as Willie states: 'it feels that this could be a blueprint to move forward - for us and for other First Nations on the coast...it was a really good ending.' Contemporary settler Canada then, is still engaging in this process of finding a means of reconciling its relationship with Indigenous First Nations through its relationship with animals. This conflict is well demonstrated in The Cure for Death by Lightning, and indeed literature is a valuable medium through which to examine settler-Indigenous issues because of the potential that fiction offers for imaginative

\footnotetext{
${ }^{3}$ Leyland Cecco, "Indigenous input helps save wayward grizzly bear from summary killing," The Guardian, Sunday 19 April 2020, accessed 10 May 2020, https://www.theguardian.com/environment/2020/apr/19/grizzly-bear-canada-indigenous-conservationbritish-columbia.

${ }^{4}$ Ibid.
} 
contemplation. Furthermore, the question of species relations is of growing prominence in academia. Having entered what scientists have termed the 'sixth extinction' of mass species, it is imperative that we find new ways of relating to and conserving the landscapes around us, and literature provides a means through which to examine our relationship with the environment. The 'cure' for better relations, Anderson-Dargatz's novel posits, much like the outcome of the recent incident on Hanson Island, is a return to Indigenous frameworks of relation.

Despite the novel's success in Canada, little critical attention has been given to The Cure for Death by Lightning. ${ }^{5}$ In particular, little engagement has been made with the text's representation of human-animal relations, despite Coyote's animal status and the agricultural setting of the novel. Heidi Slettedahl Macpherson identifies the novel's pitfalls as being located in gender conflict. She argues that, rather than symbolising an 'aboriginal claim', Coyote is: 'The unnamed "it" who follows Beth Weeks, frightens her, and abuses her...Coyote is the name of her unmentionable fear: of her father, of other men, of boys...An adolescent, Beth is at risk of sexual assault both within the home and outside of it.' ${ }^{6}$

The haunting characterisation of Coyote is, for Macpherson, a symbolic reflection of a feminist critique of a specific set of gender dynamics. However, such an analysis overlooks the territorial disputes governing this region and the Indigenous story and characters that frame the novel, eradicating Indigeneity entirely from the text. In contrast, in Marlene Goldman's critical comparison of Sheila Watson's The Double Hook and Gail Anderson-Dargatz's The Cure for Death by Lightning she

\footnotetext{
${ }^{5}$ In Canada: shortlisted for the Giller Prize (1996). Awarded the Ethel Wilson Fiction Prize (1997). Bestseller in Canada (selling over 100,000 copies). In the UK: Bestseller \& winner of Betty Trask Award (1998).

${ }^{6}$ Quote taken from Heidi Slettedahl Macpherson, "Coyote as Culprit: The Coyote Aesthetics of GailAnderson-Dargatz's The Cure for Death by Lightning", British Journal of Canadian Studies 17, no. 2 (2004): 178.
} 
situates the novel within the Canadian gothic tradition and argues that the haunting element of the text represented by Coyote is underpinned by a postcolonial critique:

[The text] register[s] the uncanny status of Canada and British Columbia, in particular, by representing conflicts between those aligned with the patriarchal, Christian, settler community and those aligned with the unsettling trickster-god Coyote. A transformer-god who provided sustenance for his people, Coyote embodies, for the settler-invader society, the uncanny, Aboriginal claim to the land. ${ }^{7}$

This critique identifies the settler-Indigenous conflict represented in the novel by way of Coyote, and Goldman goes further to add that the failure of the novel lies in its representation of Indigenous characters. She states that 'the threat posed by independent, phallic women is projected specifically onto Native women', pathologizing them. ${ }^{8}$ Consequently, 'the cure is figured as the death of female and indigenous agency and subjectivity. ${ }^{9}$ Differing to both of these arguments, however, this article asserts that Goldman's analysis fails to engage with the ways in which female agency is actually developed and advocated in the novel through interactions with non-human animals. By way of examining the representation of species in the novel and by acknowledging Coyote in a Shuswap context, I argue that rather than projecting 'phallic' energy onto the female Indigenous characters; they are depicted as empowered through embracing eco-sexuality and drawing upon their feminine identity to relate to the non-human inhabitants of the landscape.

Inevitably, the use of an Indigenous myth by a settler writer raises questions of cultural appropriation, but this has also been notably absent from criticism of the text. Lenore Keeshig-Tobias (Anishinaabe) argued in 1989 that 'the stories and cultures of

\footnotetext{
${ }^{7}$ Quote taken from Marlene Goldman, "Coyote's Children and the Canadian Gothic: Sheila Watson's The Double Hook and Gail Anderson-Dargatz's The Cure for Death by Lightning," in Unsettled Remains: Canadian Literature and the Postcolonial Gothic, eds. Cynthia Sugars and Gerry Turcotte (Waterloo: Wilfred Laurier University Press, 2009), 53.

8 Ibid., 109.

9 Ibid., 63.
} 
the First Nations (and, by extension, other minorities) should not be appropriated by non-native writers': 'You know, in our culture, people own stories...Individuals own stories... Families own stories...Tribes own stories...Nations own stories...And there is a protocol if you want to tell those stories: you go to the storyteller...And if you don't and you start telling those stories, then you are stealing. ${ }^{10}$

By this argument, to overlook such a particularized relationship to these stories is to expose either one's ignorance to cultural differences or one's wilful desire to steal and use these narratives despite these differences. In a similar critique, Diana Brydon has commented on non-Indigenous, settler-Canadian writers of fiction utilising Indigenous myths and aspects of culture in their work, arguing that it 'serves a white need to feel at home in this country and to assuage the guilt felt over a material appropriation by making it a cultural one as well. ${ }^{11}$ It is imperative to acknowledge that Anderson-Dargatz is not a First Nations tribal member and yet has created a novel in which the narrative is entirely constructed around Shuswap characters and stories. The complexity and nuances of this issue are, however, further encapsulated by Daniel Morley Johnson, who argues that settler engagements with Indigenous knowledge and beliefs might be a positive move towards the inclusion of Indigenous beliefs within wider cultural understanding:

The recent scholarship of North American Indigenous literary nationalist critics has emphasized the need for work that responds not only to the intellectual paradigms of Indigenous nations, but also to the needs of Indigenous communities. Unlike some Indigenous Studies academics, I do not take this call for accountability to mean that only Indigenous people can write about Indigenous literature. In fact, nationalist critics explicitly state the

\footnotetext{
${ }^{10}$ Quote taken from: Margery Fee, "The Trickster Appropriation, Imagination in Moment, and the Canada Cultural Liberal," in Troubling Tricksters: Revisioning Critical Conversations, eds. Deanna Reder and Linda M. Morra (Waterloo: Wilfrid Laurier University Press, 2010), $163,70$.

${ }^{11}$ Quote taken from Diana Brydon, "'The White Inuit Speaks': Contamination as Literary Strategy," in Post-Colonial Studies Reader, ed. Bill Ashcroft (Abingdon: Routledge, 1994), 141.
} 
opposite - they simply and rightfully demand a meaningful, informed engagement with Indigenous peoples and their texts. This approach, according to Daniel Heath Justice (Cherokee), "is not a necessarily exclusivist act that seeks an idealized cultural purity," but rather "a deeply realistic and life-affirming act."12

The important takeaway here is the notion of forming 'meaningful informed engagements' with Indigenous peoples and their literature, but this does not account for effectively re-writing Indigenous stories as a settler author. Whilst this article will attempt to identify moments within Anderson-Dargatz's novel that do amount to meaningful engagements with Shuswap ways-of-being, such as through the incorporation of the story of Coyote into a serious fictional contemplation of humananimal relations, it will maintain an acknowledgement of the novel as a piece of settler literature that relies on Indigenous spirituality as a framework for its plot.

To carry out an analysis of the novel, the priority of this article is to centre Indigenous theories and epistemologies. This is because, as Billy-Ray Belcourt (Driftpile Cree Nation) argues: 'Critical Animal Studies (CAS) and mainstream animal activists have generally failed to center an analysis of settler colonialism and therefore operate within "the givenness of the white-supremacist, settler state."' 13 It is therefore imperative to approach our 'theories of animality'14 through a decolonial lens if we are to successfully recognise and incorporate Indigenous epistemologies into the conversation. In addition, Belcourt adds that 'Indigeneity ought to be at the core of any theory of ethical living, ${ }^{15}$ reinforcing the importance of examining the

\footnotetext{
${ }^{12}$ Quote taken from Daniel Morley Johnson, "(Re)Nationalizing Naanabozho: Anishinaabe Sacred Stories, Nationalist Literary Criticism, and Scholarly Responsibility," in Troubling Tricksters:

Revisioning Critical Conversations, ed. Deanna Reder and Linda M. Morra (Waterloo: Wilfrid Laurier University Press, 2010), 202.

${ }^{13}$ Quote taken from Billy-Ray Belcourt, "An Indigenous critique of Critical Animal Studies," in Colonialism and Animality: Anti-Colonial Perspectives in Critical Animal Studies, eds. Kelly Struthers Montford and Chloë Taylor (Abingdon: Taylor \& Francis Group, 2020), 20.

${ }^{14}$ Ibid., 24.

${ }^{15}$ Quote taken from Belcourt, "An Indigenous critique of Critical Animal Studies," 25.
} 
species element of the novel in relation to the Indigenous framework. This article will consequently examine the representation of Shuswap matriarch Bertha's femalecentred house, where chickens enter freely and lay their eggs amongst the human women, signifying the absence of regulated reproduction and the lack of spatial boundaries between human and animal spaces. I will examine the depiction of ecosexuality operating within the novel's Indigenous spaces and reinforced through Bertha's granddaughter, Nora, and her queer identity and Bertha's decision not to remarry, as both Indigenous women place emphasis on fostering relationships outside of colonial, heteronormative convention. It will balance the argument that this involves advocating for both female agency and the centring of Indigenous epistemologies within settler fiction, whilst maintaining a critical perspective of Anderson-Dargatz as a settler author.

\section{Eco-Sexual Spaces and Cross-Species Relations}

Whereas Goldman argues that the novel erases female agency, the opposite conclusion emerges when examining the characterisation of both the settler and Shuswap women through their relationship with non-human animals. Throughout the novel Indigenous spaces, and the treatment of the animals within them, are depicted as offering a way of relating that is absent of the oppressive heteronormativity that governs Beth's father's farm. These spaces are depicted as more liberatory spaces in the eyes of Beth, who admires the way that the Indigenous women are able to express their gender more overtly through their clothing, and their relaxed and caring attitude towards interaction with non-human animals. Beth describes the way in which non-human animals appear to be attracted to and comfortable around Bertha and her daughters: 'I followed the women a little way down Blood Road; the birds 
followed them too, attracted to their glittering jewellery and bright ribbons...Purple swallows zoomed around them. ${ }^{16}$ Their bright clothing, contrasting with the 'modest' and restrictive way of dressing that Beth, her mother, and the other women of the settler community dress, is described as being a factor in their attractiveness to the birds - symbolically reflecting their different way of relating to those around them. In addition, Bertha's hair is described as 'done up in a single braid that lay down the back of her red dress, and her sleeves were scandalously rolled up to the elbow' and she wore "black stockings and moccasins decorated with porcupine quills and embroidery.' (8) In contrast, Beth's mother is described as wearing 'milking clothes, a brown housedress and gum boots, and her long, long hair was tucked away in a blue kerchief, so you'd think she had no hair at all.' (8) The absence of accessories and the covering Beth's mother's hair reflects a patriarchal control of femininity and individuality that instead ties her to her role on the farm and reinforces a particular relationship to animals that hinges upon the heteronormative regulation of agriculture. Bertha's clothing, however, incorporating decorative porcupine quills, indicates towards a different kind of relationship with non-human animals: one that operates outside of heteronormativity and incorporates animal skins and feathers into a cultural aesthetic.

The novel's depiction of Indigenous female characters as freer and more creative in their dress and also as incorporating non-human animals into their clothing is further reinforced through Bertha's daughters and granddaughters. Beth notes that 'each girl's hair was black, oiled with bear grease so it shone, and tied back with all manner of barrettes and ribbons.' (9) This quotation again demonstrates

\footnotetext{
${ }^{16}$ Gail Anderson-Dargatz, The Cure for Death by Lightning (Toronto: Random House of Canada,
} 1997), 15. 
the use of materials from non-human animal bodies as a source of decorative aesthetic, much like Bertha's porcupine quills. It signifies a particular relationship with non-human animals that is integrated into their culture and uses all aspects of the non-human animal, rather than mass-producing specific cuts of meat and disposing of the unused bodies. Additionally, Bertha's relations are not forced to conform to gendered clothing stereotypes, nor are they forced to be modest, as 'one of the daughters' wore boys' jeans and a western shirt that stretched a little at the buttons across her breasts' and, despite being Beth's age, 'she wore lipstick and a necklace of bells strung together.' (9) The freedom with which Bertha's relations are able to choose their own clothing is something that Beth envies. Throughout the novel she dreams of owning stereotypically feminine items of clothing, like lipstick and this necklace, that are considered promiscuous by her father. Of Bertha's daughter's necklace, she states: 'I coveted that necklace...She saw me looking at it and jingled it, and the room filled with tinkling notes that lit up everyone's face.' (9) The joy that the sound of this necklace brings to the room reflects a desire for a more libertarian way of living, which Beth perceives not only to be feminine and womanly, but also Shuswap.

The particularised relationship that the novel's Shuswap characters are represented as holding to non-human animals draws upon a common theme within Indigenous storytelling more broadly. Melissa K. Nelson (Anishinaabe/Métis) argues that many North American Indigenous stories have often indicated that 'women have a distinct role as mediators between humans and other beings' because 'they are fluid boundary crossers who can enter and maintain erotic intimacy and economic 
trade with nonhumans. ${ }^{17}$ This connection between gender and the crossing of boundaries to establish more intimate relations is evident in Anderson-Dargatz's novel when a chicken flies in through the window at Bertha's house: 'The women all laughed...I started to get up, to help catch the chicken, but Nora held my arm...We all watched the chicken nestle a place for herself among the magazines and rabbit fur on the mattress, cluck and croon and lay an egg.' (116) Beth's instinct to try to remove the chicken from the house evidences her settler-based binary understanding of the space as a human domestic space, and thus not somewhere for animals to enter.

This conception of constructing spatial boundaries for animal presence is discussed by Chris Philo and Chris Wilbert, who determine that the transgression of animals into these determined 'human spaces' renders them 'beastly places' through the agency demonstrated by the animal entering such space, as they 'count[er] the proper places stipulated for them by humans, thus creating their own "beastly places" reflective of their own "beastly" ways, ends, doings, joys and sufferings. ${ }^{.18}$ For Beth this is a spatial transgression and as such an assertion of agency by the chicken, which is unfamiliar to her. However, the indifference of Nora and the other women indicates that this is a regular occurrence, supported by the chicken's willingness to 'nestle' in the house and their nonchalant laughter at it doing so. In Bertha's house, there are no spatial divisions between human and animal habitation because there are no such distinctions between species and privilege, and indeed Philo and Wilbert

\footnotetext{
${ }^{17}$ Quote taken from Melissa K. Nelson, "Getting Dirty: The Eco-Eroticism of Women in Indigenous Oral Literatures," in Critically Sovereign: Indigenous Gender, Sexuality and Feminist Studies, ed. Joanne Barker (Durham: Duke University Press, 2017), 244.

${ }^{18}$ Quote taken from Chris Philo and Chris Wilbert, "Introduction," in Animal spaces, beastly places: new geographies of human-animal relations, eds. Chris Philo and Chris Wilbert (Abingdon: Routledge, 2000), 13.
} 
recognise that there is often a difference in understanding of human-animal spatial relations in Indigenous cultures:

With the taking seriously of 'other' knowledges—notably non- Western 'indigenous' knowledges or ethnosciences—which provide a less dualistic account of the differences between humans and animals, many people (outside the West, but in it too) have started to deconstruct seemingly obvious claims about the privileged status of the human, in contradistinction to the animal, as the source of agency in the world. ${ }^{19}$

Through the contrast in reaction to the transgressing chicken between Bertha's family and Beth, Anderson-Dargatz demonstrates a difference in knowledge regarding animals and 'animal spaces.' To the Shuswap characters all spaces are shared, which means that all spaces are in fact 'beastly places' as much as they are also human spaces, thereby eradicating the concept of 'beastly places' entirely. The agency developed in this distinction is that women are represented as the facilitators of this boundary removal, echoing Nelson's aforementioned statement.

Kim TallBear (Sisseton Wahpeton Oyate) argues that Indigenous concepts of sexuality offer a way of relating (to both humans and more-than-humans) that are less oppressive and more sustainable. This is because settler relations and concepts of family are deeply grounded in heterosexual, monogamous ideals that have been forced upon Indigenous communities globally. These types of relations are 'unsustainable kinship forms' ${ }^{20}$ and 'are not sustainable economically or materially' because they turn both the land and its inhabitants into belongings through the ownership of land bodies and water as private property on which to 'settle'. These kinds of normative, couple centred forms of relationships, which she terms 'intimate

\footnotetext{
${ }^{19}$ Quote taken from Philo and Wilbert, "Introduction," 15.

${ }^{20} \mathrm{Kim}$ TallBear, Lecture at the University of Winnipeg's Weweni Indigenous Scholars Speaker series titled "Decolonial Sex and Relations for a More Sustainable World," YouTube Video, 4:9, October 2018, https://www.youtube.com/watch?v=1ELSwPqjKkE\&t=222s\&ab channel=UWinnipeg.
} 
privilege' go 'hand in hand with discourses of evolution and race and imposition of marriage and monogamy as a technique for state management of indigenous bodies. ${ }^{21}$ Moving away from colonial frameworks for establishing relations with both other-than-humans and more-than-humans involves a 'move towards Indigenous relationality to offer more sustainable intimacies. ${ }^{22}$ This relationality is what TallBear defines as eco-sexuality. It is about establishing good relations across familial and other, including more-than-human, relations, and it does not divide the erotic between human and non-human bodies. TallBear argues that eco-sexuality 'might be powerful enough to soothe the pains of colonisation and internal-colonisation, ${ }^{23}$ rendering it a significant lens through which to examine relating and sharing of power within these relationships.

In her focus on relating, TallBear is working in proximity to Donna Haraway's definition of 'kinship', which is acknowledged by Anishinaabe critic Nelson, who says that she and TallBear 'share an interest in "greening" Indigenous queer theory and investigating how Indigenous stories portray social relations with nonhumans. ${ }^{24}$ Whilst TallBear does not specifically focus on non-human animals, Nelson does include them in her concept of eco-sexuality. She argues that interactions with other beings provide 'contact zones' in which a process takes place that she labels 'getting dirty', stating that it is 'a messy, visceral, eco-erotic boundary-crossing entanglement of difference that can engender empathy and kinship and a lived environmental ethic. ${ }^{25}$ This 'getting dirty' and reference to boundary crossing is that which is at play in Bertha's house in The Cure for Death by Lightning. Beth is exposed to a way of

\footnotetext{
${ }^{21}$ TallBear, Lecture at the University of Winnipeg's Weweni Indigenous Scholars Speaker series titled "Decolonial Sex and Relations for a More Sustainable World," 6:44.

22 Ibid., 7:50.

${ }^{23}$ Ibid.,19:10.

${ }^{24}$ Nelson, "Getting Dirty," 234.

${ }^{25}$ Ibid., 232.
} 
relating that involves 'getting dirty' with the chicken and normalising sharing intimate space with it. In addition, the significance of the chicken laying an egg is that it reinforces Bertha's house as a place that specifically nurtures women and female energy, including other-than-human beings, such as animals, to the extent that female animals feel comfortable enough to enter it and lay their eggs amongst their female human relations. This nurturing energy echoes Nelson's argument that 'embracing our eco-erotic nature helps us recognise the generosity of creation, and our part in it, so we can truly embody the ethic of kinship. ${ }^{26}$ In Bertha's house then, a space governed by Shuswap knowledge systems that do not conform to a binary way of conceiving human-animal relations, all female bodies are celebrated, normalised and nurtured.

In contrast, on Beth's father's farm, the animals are confined within specific enclosures away from the house and their bodies are regulated and governed within specific agricultural or domestic guidelines. Despite her non-Indigenous identity, the novel's protagonist Beth demonstrates a desire to foster better ways of relating to non-human animals, expressing empathy where her father shows indifference. This is evidenced in Beth's desire to comfort a cow that her father readily operates on to remove her ovaries. She states that 'the cow bawled and bawled...I wanted to stroke her, to offer her some comfort, but I had to keep her head straight.' (84) Once her father has finished his butchery, Beth is able to demonstrate her kindness towards the cow: 'I filled a bucket with water and put it in front of her and smoothed the hair between her horns.' (100) The contrast between her father's previous handling of the cow 'as if he was carving the Sunday roast' (84) with her 'smoothing' touch evidences his nonchalance and her empathy for the cow. In addition, the idea that in slicing into

${ }^{26}$ Nelson, "Getting Dirty," 255. 
a cow Beth is reminded of her father carving dinner is particularly melancholy because it indicates that family life and the preservation of nuclear family ideals, such as sitting at the table to eat a Sunday roast, are founded on inherently violent sources - both colonially through the displacement of the Indigenous Nations who lived on the land that they now farm, but also to animals, through the exploitation and consuming of their bodies.

The sympathy that Beth demonstrates is fostered also through the practice of milking. Whereas Beth describes her father's rough technique as 'yanking', and her brother's as extremely slow, she refers to the way in which her mother and herself milk as a time during which a type of intimacy between the two female species is realised, culminating in a calm and intimate encounter: 'Mostly it was my mother and I, milking to the rhythms of our own heartbeats, so close sometimes that the milk squirted into the pails in unison, like an iambic drumbeat...My mother sang quietly, and we milked with our heads against the warm flanks of our cows...They knew us enough to trust us.' (39) By describing the rhythm of their milking as an 'iambic drumbeat', Beth likens the milking of the cows to a poetic metre, which emphasises the effortless musical flow of their practice and their synchronistic union. Beth also enforces the idea that the cows permit this intimacy, evidenced by their allowing of her and her mother to rest their heads against their flanks, in contrast to their tendency to kick her father. There is an affinity between Beth, her mother, and the cows, that is dependent on their gender and fosters individualised, intimate relations that have moved beyond heteronormative logic and into an excess of the erotic through the repeated emphasis on touch and proximity. Beth's and her mother's gentle touching of the cows cultivates an eco-sexual, cross-species intimacy that is not dependent on the violence underpinning the wider running of the farm and the 
emotionless regulation of female bodies, but instead privileges and nurtures the female body and its reproductive capacity unknowingly from within a framework similar to that practised by the Shuswap characters.

Beth's kindness towards the cow, and her witnessing of Bertha and her daughters' way of relating to the chicken, positions her as a character that desires to engage with this Indigenous coded female-centred way of relating. This is evidenced through her admiration of Bertha as a figure of resistance against her father, the refuge that she finds in the Indigenous female spaces that Nora, Bertha's granddaughter, shows her, and in her sexual curiosity towards Nora, which indicates her attraction to non-heteronormative ways of relating.

Nora takes Beth to an underground 'winter house' (131) that belongs to Bertha. She decrees in humorous thinly veiled misogyny that this 'winter house' was intended for women and was built underground because it was considered bad luck for a man to have a woman over him. The house is, however, more likely to be the remains of a Kekuli, otherwise referred to as a quiggly, which is an underground structure built by the First Nation people of British Columbia. The remaining quiggly towns in the province have become significant components in Settler-First Nation territorial disputes, since their existence serves as proof of historical Indigenous claims to the land. This reference to a site of significant territorial conflict connects the space in which the novel is set to a deep Indigenous history, and specifically to a female history. Nora states: 'Granny lived there when she was small...That was my great-granny's house...Then it was Granny's house...My mum wants nothing to do with it, so I guess it's mine now, eh?' (112) The winter house then, becomes a space in which Beth seeks refuge from her father and his strict control of her behaviour by 
imaginatively indulging in what she determines as Shuswap ways of living. This includes the opportunity to perform the femininity that she craves:

A place to go that my father wouldn't know about. A place no one would know about. l'd take my little treasures there, my violet perfume, my nail polish, the scrap of red velvet, and other things too, that l'd planned on getting, a pair of nylons, a tube of lipstick, a dress with a bit of red on it, maybe at the collar, a racy girl's dress, something to dance in. (131)

It is the absence of men and male control of the winter house that positions it as a safe space for Beth to carry out these gender performative fantasies. Beth's life on the farm does not allow her to express her femininity in the way that she desires, both because her father does not allow her to, but also because in the presence of men, such as her father and Dennis, her femininity renders her vulnerable to their advances. Her visits to the Kekuli and her perception of the space as somewhere she can escape to does however, also demonstrate her naivety. Rather than recognising the remains of the winter house as evidence of the displacement of Nora and her ancestors, Beth envies Nora and her seemingly free, unattached lifestyle. This moment, then, reflects the thin line the novel traces between attempting to restore agency to the female characters, particularly the Shuswap characters, and simultaneously reducing the colonial experiences of the Indigenous women into avenues of relief for Beth through this settler framing of the novel.

It is necessary to note that part of the process of Beth witnessing and admiring Bertha and her daughters' lifestyles and relationship with animals involves Beth inserting herself into these Shuswap spaces. Aside from the Kekuli and Bertha's kitchen, this extends beyond the material and into more spiritual concepts of space, such as ritual spaces. Beth witnesses Nora performing a kind of ritualised dance and enters the circle that Nora has drawn: 'she stamped out a circle in the dirt...Her movements were precise, as in a ritual, and the bell necklace sounded and 
shimmered to the beat.' (183) Nora's necklace contrasts with Beth's modest dress, and reinforces their governance by differing social ideology. To Beth, Nora's culture is embedded with sound, movement, and physical expression, whereas hers is governed by the control of an abusive and miserable father. By entering Nora's circle Beth symbolically demonstrates her desire to access the freedom she perceives in Nora as a means of escaping her current patriarchal existence. She does this despite her non-Indigenous identity and the over-arching question of the appropriateness of her presence within the spaces, again reinforcing her ignorance of the region's settler-Indigenous history and demonstrating her naivety regarding Nora's experience as a Shuswap girl.

Despite this, Nora does demonstrate an obvious affection for Beth: 'Nora stepped inside the circle and held out her arms...I stepped into the circle with her and wrapped my arms around her and we held each other until I heard my mother and father driving home.' (183) The temporality of their embrace reinforces Beth's position as an outsider, or intruder, within this space. Ultimately, she will always return to her settler life on the farm, governed by a heteronormativity that, to use Scott Lauria Morgensen's term, is 'settler sexuality'. He argues that the heteronormative familycentred tradition favoured by settlers is a colonial relic that has not only defined hetero-marital life as the norm, but it has also been used to supplant Indigenous beliefs surrounding ways of relating: 'Colonization produced the biopolitics of modern sexuality that I call "settler sexuality": a white national heteronormativity that regulates Indigenous sexuality and gender by supplanting them with the sexual modernity of settler subjects. ${ }^{27}$

${ }^{27}$ Quote taken from Scott Lauria Morgensen, "Settler Homonationalism: Theorizing Settler Colonialism within Queer Modernities," Journal of Lesbian and Gay Studies 16, nos. 1-2 (2010): 106. 
Sexuality, and the regulation of it, is then, an influential tool of colonization. ${ }^{28}$ Thus, by spending time with Bertha and Nora in their homes, Beth is exposed to an alternative way of living that incorporates non-human animals in a way of relating outside of settler sexuality. Through such representation, the novel works to expose the violence and control that underpins settler-hierarchies and social relations by depicting Shuswap ways-of-relating as being kinder and more liberating through a pro-woman and pro-animal ethical proximity. Anderson-Dargatz therefore forges a connection between settler-sexuality and violence towards non-human animals that aligns itself with both Nelson's and TallBear's arguments, which is destructive for both humans and more-than-human beings. In doing so, the novel privileges Indigenous ways of relating, and concepts such as eco-sexuality, as sources of knowledge surrounding the discourse of and intersection between gender and species that must be taken seriously.

\section{Queer Coyote: Indigenous Queer Opposition to Settler Sexuality}

Building on this positioning of Shuswap ways of relating as a critical reconfiguration of the heteronormative knowledge system, the novel also develops queer representation as a means of disrupting settler sexuality through Bertha's daughter Nora. This is done by way of linking her to Coyote. Jodi A. Byrd (Chickasaw) states: 'The queer in Indigenous studies...challenges the queer of queer studies by offering not an identity or figure necessarily, but rather an analytic that helps us relocate subjectivity and its refusals back into the vectors of ongoing settler colonialism. ${ }^{29}$

\footnotetext{
${ }^{28}$ Beyond the more systematic imposition of heteronormative monogamy there are, of course, resistance sexual practices at work in Canada. Such are explored in Christopher Lane's Ruling Passion: British Colonial Allegory and the Paradox of Homosexual Desire (1995).

${ }^{29}$ Quote taken from Jodi A. Byrd, "Loving Unbecoming: The Queer Politics of the Transitive Native," in Critically Sovereign: Indigenous Gender, Sexuality and Feminist Studies, ed. Joanne Barker (Durham: Duke University Press, 2017), 226.
} 
Nora's characterisation then, becomes a source through which to further critique and oppose settler sexuality, reinforcing the purposefully troubling nature of the Coyote figure. Nora is associated with the trickster through her tendency to repeatedly surprise Beth with her appearance on a number of occasions when Beth feels like she is being followed, fearing it is Coyote. Despite this 'haunting' connection, Beth's interactions with Nora are physically affectionate and engaging on a sensory level, and they are absent of the abuse and coercion that marks the abuse she receives from her father, and her later attack by Coyote Jack. She remarks that Nora, 'ran her fingers along the back of my hand, petting me...The thing was so unexpected, so thrilling, so soothing, I just stood there breathless, letting it happen.' (73) Her surprise at having been touched in this way by a woman exposes the heteronormative lens she has become accustomed to, and her enjoyment of it reveals a queer curiosity. Beth acknowledges her confusion regarding her feelings for Nora, stating that 'looking at her confused me...We were both just girls' and '[she] kissed me like a lover.' (132) Beth's bewilderment stems from both her immaturity and sexual innocence, being 'just a girl', and because their gender complicates Beth's heteronormative understanding of relationships. Her description of being kissed 'like a lover' reads as an internalised attempt to affirm the nature of their relationship as being beyond a friendship and into the realms of queer sexual curiosity.

Nelson argues that 'Native oral narratives show us the adventures, benefits, risks, and consequences of following women's desires, and trickster stories show how ambivalent and complicated our desires can be. ${ }^{30}$ Nora's association with the trickster figure is a demonstration of this at play, and the narrative between Nora and

\footnotetext{
${ }^{30}$ Nelson, "Getting Dirty," 254.
} 
Beth becomes a sub-story about desire in itself. Beth is repeatedly drawn into Nora, stating: 'She kissed me with all of her body and went on kissing me even when I tried to pull away, kissed me until I didn't want to go anymore... Then she stopped me, leaving me pumped with desire, sweating in it.' (271) Nora's ability to leave Beth 'pumped with desire' emphasises the queer sexual awakening that the relationship with Nora as a Coyote figure offers Beth, drawing her further out of the confines of her heteronormative world and into a one that is sexually ambiguous, absent of specific labels pertaining to sexuality, and full of curiosity and desire.

Shane Phelan maintains that there is a convincing connection between trickster figures and lesbianism more broadly. This, he argues, is because both involve a state of 'fluidity in the formation of one's identity - that which he terms 'shape-shifting' - and the social benefits of being able to disguise oneself:

The shape-shifting is the product not of some unique facility of lesbians, but of the rigidity of social codes that make lesbians invisible unless they are conforming to dominant stereotypes. It is in Coyote's "nature" to appear as not-Coyote when it suits his purposes. Some may recognize, or suspect, Coyote when he is transformed, but Coyote has the ability to fool most people and to get his way. Coyote uses our own expectation to slip under our radar. One implication of this analogy might be that lesbians can gain power from sneakiness and subterfuge, from masking themselves. ${ }^{31}$

This is not to suggest that lesbians are 'sneaky', but rather to emphasise that the likeness of Nora to Coyote stems from the fact that her sexuality is not outwardly visible, it is possible to keep it personal and hidden. Furthermore, Phelan perceives lesbianism as a sexuality that does not conform to patriarchal heteronormativity. It is evident that the notion of Nora as a romantic interest is not on Beth's parents' radar and Nora is able to navigate her way into Beth's life precisely because Beth's family

${ }^{31}$ Quote taken from Shane Phelan, "Coyote Politics: Trickster Tales and Feminist Futures", Hypatia 11, no. 3 (1996): 139. 
does not perceive her to be a threat in the same way that they perceive male characters and their potential for sexual advances to be a threat. Consequently, as the story of Coyote brings into question the validity of the 'bear attack' perpetuated by the settler characters, disrupting settler conceptions of human-animal relationships, so too does Nora become a 'trickster figure' through both her queer-ness and her Shuswap identity: challenging settler-sexuality and navigating the landscape using her intimate familiarity of the area in a stealthy fashion, like the animal trickster. Beth states: 'I saw a motion in the grass coming towards me, a splitting of the grass as if an animal or a man were running through it.' She then adds: 'the swishing of the grass filled up my ears and came at me faster than anything possible...Then a hand was on my shoulder...I swung around and Nora was there.' (129) The appearance of Nora in the place of a 'man or animal' is a relief for Beth, but it still aligns Nora with mystery through both her ability to approach Beth undetected and through the elusive and animal-like nature of her physical form in the grass. This ability to go unnoticed, Goldman points out, contributes to a ghost-like characterisation of Nora: 'Scene after scene aligns Nora with Coyote, rendering her phantom like perhaps because, as Terry Castle asserts, "to love another woman is to lose one's solidity in the world, to evanesce, and fade into the spectral."'32

Such an argument positions Nora's lesbian identity as that which renders her a 'ghostly', elusive presence, much like Coyote, but it emphasises that this happens due to a detachment from patriarchy. To exist outside of patriarchy, Goldman reads, is to 'fade into the spectral'. However, I would argue that the novel complicates this reading by rendering Nora a complex figure that offers both comfort and protection to Beth, in that rather than fading, Nora is depicted as defiant and representative of an

32 Goldman, "Coyote's Children and the Canadian Gothic," 60. 
agency that Beth envies. Nora often appears during moments in which Beth is particularly frightened and offers relief through her presence. As such, Nora is depicted as an extension of the female-centred way of relating visible in Bertha's house, moving beyond familial and kinship-like relations and into the erotic.

It is possible to connect this to still important forms of queer critique established in relation to lesbian feminism in the 1980s, in which lesbianism was reclaimed as 'an assertion of sexual agency and feelings, but autonomous from men, a reclaiming of erotic drives directed toward women, of a desire for women that is not to be confused with women identification. ${ }^{33}$ Nora's lesbian identity figures her as a character that inherently challenges the patriarchal regulation of sexuality by way of excluding them through her sexual orientation. Thus, her alignment with Coyote in the novel symbolically reflects the propensity for the Indigenous 'trickster' figure to shed a nuanced light upon feminist politics. Phelan states that: 'Coyote can refresh lesbian and feminist politics by offering us a less stable understanding of identity and a looser and lighter, and therefore more empowering, interpretation of the political cosmos and human action. ${ }^{34}$

Thus, by including this Indigenous story and queer characterisation within her novel, Anderson-Dargatz positions Shuswap knowledge systems as a viable alternative and way of understanding the complexities and multiplicities of feminist approaches, and the limitations of settler feminism to incorporate Indigenous women's experiences. Moreover, Nora's alignment with an animal trickster figure incorporates the question of species into the feminist equation, as it suggests that Indigenous concepts of feminism are complicated by spiritual human-animal

\footnotetext{
${ }^{33}$ Quote taken from Teresa De Lauretis, "Sexual Indifference and Lesbian Representation," Theatre Journal 40, no. 2 (1988): 162.

${ }^{34}$ Phelan, "Coyote Politics: Trickster Tales and Feminist Futures", 123.
} 
relationships, and figures such as Coyote. Through such a characterisation, Coyote aesthetics are positioned as a valuable framework for reconfiguring settler sexualities because through the trickster's very nature, cultural hegemonies can be troubled and resisted.

\section{Man, Coyote, coyotes: Human Possession by Animal Spirit}

The fluidity that the Coyote aesthetic applies to the character of Nora is more prevalent in the sinister characterisation of the male characters that are allegedly possessed by Coyote himself. The descriptions of these men repeatedly shifts and interchanges between man, coyote, and Coyote, conflating the three and consequently muddying species boundaries and troubling the responsibility that has been placed upon non-human animals in the vilification of the bear at the beginning of the novel. Such a depiction, destabilising norms, embodies the characteristics of the trickster figure, creating an ambiguous, elusive and 'shape-shifting' narrative that plays with fixed conceptions of species relations. Anderson-Dargatz's use of the Coyote story encourages us to broaden our epistemological understanding of human-animal relations by problematizing the anthropocentrism underpinning the settler culture in the novel by widening the understanding of animal species beyond just the material, lived animal and into the spiritual realm. This undermines Eurocentric humanist secularisms' work as a guarantor of human exceptionalism. Phelan argues that trickster figures are complex and cunningly versatile: Tricksters can adopt the shape of other beings for camouflage or to get what they want, though some people recognize or suspect tricksters despite their disguises. Coyote may appear as a human, another animal, or even an object such as driftwood when it serves his 
purposes. This attribute facilitates deceit and contributes to Coyote's bad reputation, but it serves to remind us that things are not always as they seem. ${ }^{35}$

Thus, whilst Coyote is on the one hand, a being that Bertha warns Beth about, fearing its ability to inhabit anyone of its choosing and attack women, it is simultaneously a figure that, because of this elusive behaviour, has the capacity to bring about disruption to the social status quo. This centres the question of species within a context of reworking settler patriarchy because, through an engagement with this Indigenous story and the transformative nature of Coyote - his physical movement between human and animal - Anderson-Dargatz is able to demonstrate that there is an anthropocentrism and heteronormativity at work in the way in which Beth's father approaches both his animals and his relationship with his family. Bertha's story regarding Coyote offers an alternative narrative that repeatedly clashes with and resists the confines of traditional settler understandings of both sexuality and species, demonstrating that there are alternative ways of living in relation to the land.

Whereas the sexual experiences that Nora brought inspired desire, the representation of the men possessed by Coyote renders them threatening and frightening. Throughout the novel, the inter-changing of man, coyote and Coyote becomes increasingly sinister, all haunting Beth. She frequently notices coyotes stalking or hovering around the farm, particularly in proximity to male characters. For instance, Beth describes the way in which 'unseen by [her] father, a coyote skulked through the long grass behind him.' (210) Moreover, in an exchange between Beth and Nora, the proximity yet distinction between coyotes and Coyote is evidenced: "Billy thinks I got Coyote following me," I said.

${ }^{35}$ Phelan, "Coyote Politics: Trickster Tales and Feminist Futures," 135. 
"Coyotes will follow anything," she said. "They're as curious as dogs."

"No, he means Coyote, that spirit thing your granny talks about." (259)

Nora's reference to curiosity explains both the reason why wild coyotes might venture close to Beth and the farm, but it also sheds light on the reason the trickster figure might present in coyote form. Both are curious navigators of the land, following those that pique their curiosity. Macpherson maintains that 'Coyote is a compelling figure, not least because of his connections to the coyote, or Canis latrans, who is stereotypically seen as a wily scavenger, with a sly smile and a mangy appearance. ${ }^{36}$ Moreover, Phelan implicates the historical resilience of the coyote species in comparison to other canine species, such as the wolf, in its' connection to its 'trickster' configuration. He states that 'the coyote is scorned as a pest but it survives. ${ }^{37}$ It is also worth noting that coyotes are wild animals, unlike the cows and chickens on Beth's farm, and so their freedom from domestic regulation means that they are well situated to reflect a spiritual figure's challenge to a type of humananimal relationship that is not oppressively governed, instead free to roam the landscape undeterred. The novel plays around with this knowledge of coyotes, using the material characteristics of the animal and their repeated 'haunting' of the North American plains as wild animals, to narratively breakdown our comprehension of what is haunting Beth.

Despite the presence of actual coyotes, Beth experiences visions of men shape-shifting between their human form and a coyote body. Such representations do challenge the domestic v. wild binary that focusing simply on coyotes perpetuates by introducing an entirely new epistemological understanding of human-animal relations. The Shuswap characters' understanding of Coyote possession, which Beth

\footnotetext{
${ }^{36}$ Macpherson, "Coyote as Culprit," 177.

${ }^{37}$ Phelan, "Coyote Politics: Trickster Tales and Feminist Futures," 134.
} 
begins to witness in the male characters around her, posits that a non-human animal spirit can possess human, muddying clear, anthropocentric boundaries. Beth states: 'Sometimes I think I'm being followed, and I never see it, exactly...But it leaves footprints...It's got hands.' (120) This description of 'hands' suggests that it is human. However, later, in a more tense moment of haunting, Beth states: 'I saw a motion in the grass coming towards me, a splitting of the grass as if an animal or a man were running through it.' (129) Her inability to distinguish between animal and man contributes to a ghostly and indecipherable conception of the figure that underpins Beth's fear. This is well evidenced in a scene of sexual assault involving her father within her own bedroom, when Beth describes a set of dead coyote skins that are hanging on her bedroom wall as coming alive and entering her dreams, only for her to realise that she is awake, and for the coyotes to turn into her father:

A darkness crossed the window and fell on my chest. When I cried out, the coyotes put their claws over my mouth. They lifted my nightgown. They rubbed their wet tails between my legs and over my belly. They told me to keep quiet. I hid my dream self in the darkest corner of my room and watched the shadows of the coyotes suck the breath from my body. When they had their fill, the shadows sighed deeply, came together, and took the form of my father. He lifted his weight from my body and left the room. (264)

Beth's dream-like state is likely to be a state of self-preservation, as she detaches her emotional 'dream self' from her physical body. In this haunting description, her father's violent ferocity is akin to an entire pack of coyotes, amalgamating the numerous coyote figures that have haunted her like 'darkness' throughout the novel into one horrific encounter that continues to blur human and animal bodies. This conflation distorts the clarity of the situation, further echoing the complex Coyote-like narrative framing of the novel and the spiritual element that underpins the possession of the men through the constant shape-shifting. 
This shifting between man and coyote occurs also in an encounter with Coyote Jack, a ghostly figure that haunts the backdrop of the novel's narrative in a similar fashion to the numerous coyotes. Nora states: 'Coyote Jack's not shy, he's bushed... He really is a coyote... He fades into the trees like magic...I've seen him...Granny says he's lived too long in the bush...The bush makes you change shape, takes away your man-body, makes you into an animal.' (132) Nora's adjective 'bushed' indicates that Coyote Jack's condition is a familiar result to her of spending too long in the wilderness. Moreover, this description solidifies the concept of Coyote possession by suggesting that Coyote Jack really is a literal shape-shifter and is therefore neither exclusively human nor animal. Instead, he has been 'made into' an animal, which implies both a physical and mental transformation, yet he remains primarily visible in his human form. This concept of shape-shifting - losing your 'manbody' and surrendering to animality through a blurring of these boundaries rather than a binary perception of them - is later confirmed when Coyote Jack attacks Beth in the woods, throwing her to the ground:

Suddenly he got up. He twisted, batted the air, and screamed, and the scream became a howl. His body flitted back and forth between man and coyote, then the coyote dropped on all fours and cowered away from me. He bristled and growled. I stood slowly and clapped my hands, as I would to scare off any wild animal. The coyote turned and trotted off and disappeared into the bush. (272)

Coyote Jack's transformation here appears like an internal battle of wills - himself against Coyote, 'flitti[ng] back and forth' - struggling between attacking Beth as Coyote and restraining himself in his human form. Eventually, when he is in coyote form she is able to frighten him off the way that she normally scares off wild animals. This shape-shifting confirms Bertha's stories about Coyote to be true. The introduction of this Coyote narrative thus undermines the bear attack narrative that 
occurs at the beginning of the novel by implicating Coyote and offering an alternative understanding of human violence, rather than animal. It interrogates the way in which culpability and violence can be misplaced onto non-human animals when an understanding of human-animal relationships is formed through the anthropocentrism that underpins the settler colonial culture depicted in the novel.

Macpherson argues that these distinctions between man, coyote, and Coyote are not actual transformations but symbolic ones, and that Beth's haunting by Coyote is reflective of her fear of male sexual violence: "Coyote is the unnamed "it" who follows Beth Weeks, frightens her, and abuses her...Coyote is the name of her unmentionable fear: of her father, of other men, of boys...An adolescent, Beth is at risk of sexual assault both within the home and outside of it.' ${ }^{38}$

Such an analysis suggests that there is no specific Coyote figure within the novel, but rather that every man is a sexually predatory Coyote. Goldman accepts that this opens up onto a disappointing anti-feminist implication, as 'to explain repeated and prolonged sexual abuse away as Coyote possession is to reiterate the worst aspect of an anti-feminist stance: that men cannot control the "beast" within' (180) and that 'it appears to absolve men of their sexual crimes. ${ }^{39}$ Whilst AndersonDargatz is a settler writer using an Indigenous story, to argue that it is simply for symbolic means ultimately disregards the Indigenous story as a source of truth and as knowledge to be handled seriously. It refutes the implications for species relations that arise through Coyote's disruption of species-boundaries, which trouble the distinction between man and human through his possession of male bodies and through the constant reminder of his existence echoed in the appearance of literal

\footnotetext{
${ }^{38}$ Macpherson, "Coyote as Culprit," 178.

${ }^{39}$ Goldman, "Coyote's Children and the Canadian Gothic," 180.
} 
coyotes. Rather, by comprehending that Beth's encounters with men, coyotes, and Coyote remain undecipherable and complex because they are underpinned by the trickster aesthetics of Coyote possession affirms the Shuswap framework that the novel is attempting to represent. Furthermore, understanding Coyote literally means that the novel is in fact better positioned as a more intersectional feminist piece of literature. This is because, as Phelan states: 'we can use Coyote's duplicity to become more creative about feminist politics. ${ }^{40}$ The multiplicity, elusiveness, and disruptive nature of the trickster figure opens up the possibility for considering a multitude of differing perspectives and undermining the status quo in terms of sexuality, species and their intersection.

\section{Conclusion: The Question of Species in Indigenous-Settler Conflict}

If considering Coyote in the Shuswap context as a real presence within the novel means that The Cure for Death by Lightning depicts a settler character as being haunted by an Indigenous mythic figure of animality, and other settler characters as being possessed by him, what are the implications of this in a postcolonial context? The struggle brought on by Coyote possession is reflective of the way in which Indigenous knowledge systems and ways of being are still at conflict with settler ones. The two characters in the novel that are depicted as being overcome by Coyote are Beth's father and Coyote Jack, both of whom are male, settler characters, and upholders of settler sexuality through their behaviour towards Beth, and other animals in the context of her father. As such, Coyote's possession of them is intended to explicitly represent the potentiality for Indigenous ways of relating to challenge settler-sexuality and conversations surrounding species relations. This is

${ }^{40}$ Phelan, "Coyote Politics: Trickster Tales and Feminist Futures," 143. 
reinforced through the way in which Beth's father's dominant personality wanes as the novel develops, culminating in his institutionalisation and later in Beth's standing up to his advances as she explores feelings of agency inspired by the Shuswap women. The novel therefore attempts to depict Shuswap knowledge as an alternative system that is capable of destabilising settler foundations of knowledge that are inherently heteronormative and oppressive. In doing so it agrees with the kinds of arguments put forth by TallBear, Belcourt, and Nelson, pre-empting this need for settler writing to be actively decolonial in its incorporation of Indigenous epistemologies into the conversation by engaging with their stories and lifeways in meaningful and respectful ways. In this way Anderson-Dargatz's novel does take a specific interest in settler-Indigenous relationships across literary, cultural, and species boundaries.

However, despite this, the novel does still ultimately centre the settler experience and arguably uses an Indigenous story to tell yet another settler story. It thus treads a fine line between positive intention and problematic execution in its engagement with Shuswap culture. The novel encapsulates British Colombia's history of displacement through its very construction: issues over land governance and human-animal relations remain at the core of settler-Indigenous conflict, as the aforementioned crisis regarding Mali the bear on Hanson Island in 2020 reinforces. What emerges from critically examining species representation and the Coyote aesthetics of the novel is, then, that settler literature must engage and destabilize the types of oppressive hierarchies that underpin both species and settler-Indigenous relations, namely settler-sexuality and anthropocentrism, if settler culture is to follow. This must begin, though, at a literary level. Such a move emphasises the value in engaging with Indigenous stories and concepts of animality as a means of thinking 
through the relationship between literature, species, and the contemporary idea of nation.

\section{Bibliography:}

Books and Articles

Anderson-Dargatz, Gail. The Cure for Death by Lightning. Toronto: Random House of Canada, 1996.

Barker, Joanne. Critically Sovereign: Indigenous Gender, Sexuality and Feminist Studies. Durham: Duke University Press, 2017.

Belcourt, Billy-Ray. "An Indigenous Critique of Critical Animal Studies." In Colonialism and Animality: Anti-Colonial Perspectives in Critical Animal Studies, edited by Kelly Struthers Montford and Chloë Taylor, 19-29. Abingdon: Routledge, 2020.

Brydon, Diana. "The White Inuit Speaks': Contamination as Literary Strategy." In Post-Colonial Studies Reader, edited by Bill Ashcroft, 136-143. Abingdon: Routledge, 1994.

Byrd, Jodi A. "Loving Unbecoming: The Queer Politics of the Transitive Native." In Critically Sovereign: Indigenous Gender, Sexuality and Feminist Studies, edited by Joanne Barker, 207-227. Durham: Duke University Press, 2017.

De Lauretis, Teresa. "Sexual Indifference and Lesbian Representation." Theatre Journal 40, no. 2 (1988): 155-177. https://doi.org/10.2307/3207654

Fee, Margery. "The Trickster Appropriation, Imagination in Moment, and the Canada Cultural Liberal." In Troubling Tricksters: Revisioning Critical Conversations, edited by Deanna Reder and Linda M. Morra, 59-77. Waterloo: Wilfrid Laurier University Press, 2010.

Goldman, Marlene. "Coyote's Children and the Canadian Gothic: Sheila Watson's The Double Hook and Gail Anderson-Dargatz's The Cure for Death by Lightning." In Unsettled Remains: Canadian Literature and the Postcolonial Gothic, edited by Cynthia Sugars and Gerry Turcotte, 51-73. Waterloo: Wilfred Laurier University Press, 2009.

Johnson, Daniel Morley. "(Re)Nationalizing Naanabozho: Anishinaabe Sacred Stories, Nationalist Literary Criticism, and Scholarly Responsibility." In Troubling Tricksters: Revisioning Critical Conversations, edited by Deanna Reder and Linda M. Morra, 199-221. Waterloo: Wilfrid Laurier University Press, 2010. 
Macpherson, Heidi Slettedahl. "Coyote as Culprit: The Coyote Aesthetics of Gail-Anderson-Dargatz's The Cure for Death by Lightning." British Journal of Canadian Studies 17, no. 2 (2004): 175-185. https://doi.org/10.3828/bjcs.17.2.3

Morgensen, Scott Lauria. "Settler Homonationalism: Theorizing Settler Colonialism within Queer Modernities." Journal of Lesbian and Gay Studies 16, nos. 1-2 (2010): 105-131. https://doi.org/10.1215/10642684-2009-015

Nelson, Melissa K. "Getting Dirty: The Eco-Eroticism of Women in Indigenous Oral Literatures." In Critically Sovereign: Indigenous Gender, Sexuality and Feminist Studies, edited by Joanne Barker, 228-260. Durham: Duke University Press, 2017.

Philo, Chris and Chris Wilbert. Animal Spaces, Beastly Places: New Geographies of Human-Animal Relations. London: Routledge, 2000.

Newspapers and websites

Cecco, Leyland. "Indigenous input helps save wayward grizzly bear from summary killing." The Guardian, Sunday 19 April 2020. Accessed 10 May 2020. https://www.theguardian.com/environment/2020/apr/19/grizzly-bear-canadaindigenous-conservation-british-columbia

TallBear, Kim. "Decolonial Sex and Relations for a More Sustainable World." Lecture at the University of Winnipeg's Weweni Indigenous Scholars Speaker series. 17 October 2018. Accessed September 2019. https://www.youtube.com/watch?v=1ELSwPajKkE\&t=222s\&ab channel=UWinnipeg

Katy Wimherst, Interview with Gail Anderson-Dargatz. Serendipity, (2009). Accessed January 2021. http://www.magicalrealism.co.uk/view.php?story=113 